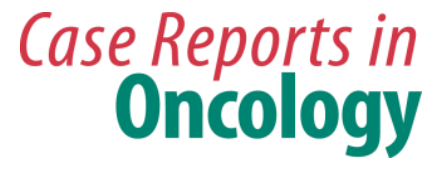

Case Rep Oncol 2017;10:66-76

DOI: $10.1159 / 000455188$

Publisned online: January 17, 2017

(C) 2017 The Author(s)

Published by S. Karger AG, Basel

www.karger.com/cro

This article is licensed under the Creative Commons Attribution-NonCommercial 4.0 International License (CC BY-NC) (http://www.karger.com/Services/OpenAccessLicense). Usage and distribution for commercial purposes requires written permission.

\title{
Gastrointestinal Stromal Tumour with Synchronous Bone Metastases: A Case Report and Literature Review
}

\author{
Philippe Rochigneux ${ }^{a} \quad$ Lénaig Mescam-Mancini $^{b} \quad$ Delphine Perrot ${ }^{a}$ \\ Erwan Bories $^{c} \quad$ Laurence Moureau-Zabotto $^{d}$ Anthony Sarran $^{\mathrm{e}}$ \\ Jérôme Guiramand ${ }^{f} \quad$ François Bertuccia, ${ }^{a}$ \\ a Department of Medical Oncology, Institut Paoli-Calmettes, Marseille, France; \\ ${ }^{b}$ Department of Pathology, Institut Paoli-Calmettes, Marseille, France; ${ }^{c}$ Department \\ of Gastroenterology, Institut Paoli-Calmettes, Marseille, France; ${ }^{d}$ Department of \\ Radiotherapy, Institut Paoli-Calmettes, Marseille, France; ${ }^{e}$ Department of Radiology, \\ Institut Paoli-Calmettes, Marseille, France; ${ }^{f}$ Department of Surgery, Institut \\ Paoli-Calmettes, Marseille, France; ${ }^{9}$ Aix-Marseille University, Marseille, France
}

\section{Keywords}

Bone metastases · Gastrointestinal stromal tumours · Imatinib $\cdot$ KIT $\cdot$ Tyrosine kinase inhibitors

\begin{abstract}
Gastrointestinal stromal tumours (GISTs) are mesenchymal tumours of the digestive tract, derived from Cajal interstitial cells. Bone metastases are very rare, and there is no consensus regarding their treatment. Here, we present the unusual case of a 66-year-old man with a gastric GIST with synchronous bone and liver metastases, fully documented at the pathological and molecular levels with a KIT exon 11 mutation. After 9 months of imatinib, the scanner showed a $33 \%$ partial response of target lesions. We also review the literature and describe the characteristics, treatment, and outcome of all cases previously reported.
\end{abstract}




\section{Case Reports in Oncology}

Rochigneux et al.: Gastrointestinal Stromal Tumour with Synchronous Bone Metastases: A Case Report and Literature Review

\section{Introduction}

Gastrointestinal stromal tumours (GISTs) are the most frequent mesenchymal tumours of the digestive tract, derived from the Cajal interstitial cells [1]. They are characterised by the presence of a gain-of-function mutation of the KIT or PDGFRA oncogenes [2]. Their incidence remains low, around 5-20 per million in different population-based studies, but their prevalence has been increasing during the last decade thanks to the therapeutic progress related to the use of tyrosine kinase inhibitors (TKIs; imatinib, sunitinib, and regorafenib) [3]. GISTs can occur anywhere along the gastrointestinal tract, but the most frequent anatomical locations are the stomach (60\%), jejunum, and ileum (30\%), followed by the duodenum $(5 \%)$, colorectum $(<5 \%)$, and more rarely the oesophagus $(1-2 \%)$ and the omentum [4]. About $40 \%$ of patients with GISTs will develop metastases, most commonly in the liver $(65 \%)$ or the peritoneum (50\%), and less frequently in the lung [5].

Bone metastases of GISTs are a very rare event. In the small series in the literature, their proportion is low $(<5 \%)$ when compared with all secondary locations [5-8]. Biologically, little is known about bone metastases of GISTs, as these metastatic sites are rarely biopsied. Particularly, it is still unknown whether bone metastases keep the same KIT/PDGFRA mutations as the primary tumour or acquire new mutations. Here, we present a case of gastric GIST with synchronous liver and bone metastases that were fully documented by pathological and molecular analysis. We also provide a review of all cases reported in the literature.

\section{Case Report}

A 66-year-old man, a retired oenologist with histories of asthma, non-insulin-dependent diabetes mellitus, and bilateral genu valgum consulted his general practitioner in November 2015 for asthenia lasting more than 6 months and left posterior intercostal pain. A thoracoabdomino-pelvic CT scan (Fig. 1a) revealed a 16-cm abdominal tumour lesion above the pancreas, associated with several suspect hepatic nodules, and multiple osteolytic lesions of the spine and pelvis. An oesogastroduodenal endoscopy found a cardial ulceration whose biopsy was negative. The patient was thus referred to our institution in January 2016.

Clinically, the patient's weight was stable, and his WHO performance status was equal to 0 . The left posterior intercostal pain was imperfectly controlled by $3 \mathrm{~g} /$ day of paracetamol, and the patient had no digestive symptoms. Physical examination found a painless voluminous tumour of the left hypochondrium; neurological examination was normal. Laboratory tests were normal, with the exception of a grade 1 increase in $\gamma$ GT. Gastric endoscopic ultrasound revealed a voluminous intra-abdominal $17-\mathrm{cm}$ tumour, in contact with the stomach, mainly necrotic, as well as multiple suspect hepatic lesions, all enhanced after injection. Pathological analysis of endoscopic ultrasound-guided fine-needle aspiration biopsies of the gastric tumour and 1 hepatic lesion revealed an epithelioid-cell gastric tumour and a spindle-cell liver tumour (Fig. 2a, b). In both specimens, tumour cells were characterised by few mitoses ( $<5 / 50$ high-power fields), no necrosis, and an immunohistochemistry (IHC) staining strongly positive for CD117 and DOG1, weakly positive for AML, and negative for desmin and PS100. The gastric tumour was CD34-negative, whereas the hepatic lesion was CD34positive (Table 1). No KIT or PDGFRA mutation was found in the hepatic metastasis, whereas 


\section{Case Reports in Oncology}

Case Rep Oncol 2017;10:66-76

DOI: $10.1159 / 000455188$

(C) 2017 The Author(s). Published by S. Karger AG, Basel www.karger.com/cro

Rochigneux et al.: Gastrointestinal Stromal Tumour with Synchronous Bone Metastases: A Case Report and Literature Review

the gastric tumour harboured a KIT exon 11 mutation (c.1676_1714del, p.Val559_Ile571del), further confirming the diagnosis of gastric GIST with hepatic metastasis.

A new staging was done in January 2016. CT scan showed an increase in size of both the abdominal tumour $(19 \mathrm{~cm})$ and the hepatic metastases as well as multiple osteolytic lesions involving notably the spine and the pelvis. ${ }^{99 \mathrm{mTc}} \mathrm{Tc}$ labelled bone scintigraphy (Fig. 3) showed several bone uptakes located on the cervico-dorso-lumbar spine, sternum, scapula, pelvis (sacrum and left sacroiliac joint), rib cage (K5-K7), left femur, and right humerus. Magnetic resonance imaging of the spine (Fig. $1 \mathrm{~b}, \mathrm{c}$ ) confirmed the vertebral bone lesions, and notably identified a T1 and T9 epiduritis and a mild medullar compression in C7, T1, and T9 without intramedullary lesion. A CT scan-guided biopsy of a lesion of the right posterior iliac bone confirmed the diagnosis of bone metastasis by a spindle-cell GIST showing the same morphological and IHC profile (Fig. 2c) as the hepatic metastasis, and the same KIT exon 11 mutation as the primary gastric tumour. The diagnosis of voluminous gastric GIST with synchronous liver and bone metastases was retained.

In February 2016, the patient started imatinib at $400 \mathrm{mg} /$ day. No local treatment was initiated for the vertebral bone lesions because of the absence of any neurological symptoms, the expected efficacy of imatinib, and the control of dorsal pain by small doses of oxycodone. In May 2016, after 3 months of treatment, CT scan showed a regression of both the primary tumour $(14 \mathrm{~cm})$ and the hepatic and bone metastases. In August 2016, after 6 months of treatment, CT scan showed further regression of the primary tumour $(12 \mathrm{~cm})$ and the hepatic metastases (RECIST 1.1 partial response with 33\% decrease in target lesions when compared to baseline) and stabilisation of bone metastases. In November 2016, after 9 months of imatinib, CT scan confirmed the partial response of the primary and hepatic lesions, which had become more necrotic, and stabilisation of the bone lesions. Currently, the patient continues imatinib, which is perfectly tolerated, without any digestive, bone, or neurological symptoms related to the tumour lesions.

\section{Discussion}

The classical metastatic locations of GISTs are the liver and peritoneum, whereas bone metastases are rare. We report here a case of gastric GIST with synchronous hepatic and bone metastases at diagnosis, documented in all sites with respect to histology and molecular biology. In epidemiologic terms, the true incidence of bone metastases remains unknown, but was reported to be between 3.2 and 5.5\% in 4 retrospective series of 53-309 patients with metastatic GISTs [5-8]. To our knowledge, 37 cases, including the present case, have been reported in the English-language literature during the last decade, including 31 since 2011. The incidence seems to be growing thanks to the longer survival of metastatic patients due to the increasing use of TKIs, as observed in other cancers responding to medical therapies in their advanced stages. All 37 cases are summarised in Table 2 and Table 3.

Bone metastases mainly occurred in men $(n=31 / 37)$ and patients older than 50 years ( $n=29 / 37)$. Like in our case, the location of the primary GIST was mainly the stomach $(n=$ $12 / 36$ informative cases), followed by the ileo-jejunum $(n=10)$, the rectum $(n=8)$, the duodenum $(n=4)$, the mesentery $(n=1)$, and the oesophagus $(n=1)$. Of note, rectal GISTs were overrepresented in that population of bone metastases, with $8 / 36$ patients $(22 \%)$, whereas 


\section{Case Reports in Oncology}

Case Rep Oncol 2017;10:66-76

DOI: $10.1159 / 000455188$

(c)

2017 The Author(s). Published by S. Karger AG, Basel www.karger.com/cro

Rochigneux et al.: Gastrointestinal Stromal Tumour with Synchronous Bone Metastases: A Case Report and Literature Review

their frequency in overall GISTs is around 5\% [4]. A likely explanation might be the haematogenous spread via the non-portal vein drainage from the rectum. Regarding the pathological characteristics, most of the primary tumours were spindle (11/20 informative cases) or mixed $(7 / 20)$, and only 2 cases, including the present one, were purely epithelioid $(2 / 20)$. Interestingly, contrary to our patient, most of the informative cases described a high number of mitoses of over 5/50 high-power fields ( $n=20 / 25)$, suggestive of intermediate or high risk of relapse. All 31 informative cases showed KIT-positive IHC staining. The mutational status of the primary tumour was documented for only 5/37 cases and showed an exon 11 KIT mutation, which is the most frequent mutation found in GISTs before any treatment.

Regarding the bone metastases, they occurred in 23/31 informative cases during the follow-up of treated primary GISTs, within a median delay of 48 months (range, 4-120 months) after the diagnosis of the primary tumour. In 8 patients, including ours, the diagnoses of primary tumour and bone metastasis were synchronous, whereas 1 case corresponded to a prevalent bone metastasis. These rare observations suggest that bone metastasis can be the initial metastatic manifestation. Like in our patient, the bone metastases mainly occurred concomitantly with or after other metastatic sites like the liver $(n=27)$, peritoneum $(n=8)$, lung $(n=4)$, or soft tissues $(n=2)$, likely through haematogenous spread via vein drainage from these metastatic sites. Their topography was mainly the spine $(n=17)$, especially thoracic and lumbar, followed by the pelvis $(n=11)$, the ribs $(n=11)$, the femur $(n=7)$, and less frequently the shoulder $(n=3)$ or the humerus $(n=2)$. Interestingly, skull or face metastases were numerous $(n=9)$, including the temporal bone, clivus, or mandible, and led to complex diagnostic investigations and surgical procedures. The discovery of bone metastases was often based on clinical symptoms or was done incidentally during diagnostic or staging thoraco-abdomino-pelvic CT scan. The bone metastases in GIST patients are classically lytic and well-defined lesions [6]. With an expanded access to magnetic resonance imaging, it is likely that more bone metastases of GISTs will be diagnosed in the future. Furthermore, bone metastases have an intense fluorodeoxyglucose uptake; in case of response to TKIs, the standardised uptake value decreases very early after the beginning of treatment, which makes PET scanning an interesting option for follow-up [9]. Unfortunately, biopsy of bone metastases was done in only $17 / 37$ cases. The pathological type was spindle cells in all 10 informative cases, similar to our case; all tested cases were KIT-positive by IHC, and only 3 cases were sequenced, showing KIT exon 11 mutation. Comparison between the primary tumour and the bone metastasis was possible for some pairs; the concordance was perfect for KIT IHC (12/12 pairs) and mutational analysis (2/2 pairs), suggesting clonal origin, whereas only 1 case (ours) showed discordant pathological type, with epithelioid type in the primary and spindle cells in the metastasis. The absence of mutation documented in the liver metastasis in our patient may reflect intratumour heterogeneity [10]. Because of the scarcity of data, it remains unclear whether a particular mutational status is associated with these unusual metastases. Efforts should be made to systematically re-biopsy such patients for mutational analyses.

The systemic treatment was based on TKIs, mainly imatinib $(n=22)$ used in 1st line, sunitinib used in 2 nd line $(n=8)$, and less frequently nilotinib $(n=2)$ or sorafenib $(n=1)$, with several "stop-and-go" attitudes due to toxicity or long-term disease stabilisation, although not recommended today [11]. Regarding the local treatment of bone metastases, the literature review showed that surgery $(n=8)$ was realised for oligometastatic patients for 
different skeletal localisations, or patients with functional impairment, sometimes associated with graft or prosthesis. Some of these patients who underwent complex surgical bone resections with R0 margins benefitted from long-term disease-free survival [12, 13]. Palliative radiotherapy was delivered to 11 patients. Even if GISTs, like soft tissue sarcomas, are often considered radio-resistant, external beam radiotherapy was associated with a significant improvement of bone pain in most of the cases. Interestingly, 1 case report described the concomitant use of imatinib during radiotherapy, with good tolerance [14]. Bisphosphonates were used in 5 patients (zoledronic acid), and 1 case of jaw osteonecrosis was described after imatinib and zoledronic combination [15]. The clinical outcome after the diagnosis of bone metastasis was available in $26 / 37$ patients: 9 patients died after a median time of 11 months (range, 1-103), whereas 17 remained alive with a median follow-up of 19 months (range, 2-187). Thus, although bone metastases occurred preferentially in high-risk metastatic GISTs, their prognosis was not particularly dreadful.

In conclusion, bone metastases of GIST are rare but likely underdiagnosed, and their frequency is increasing because of the improvement of imaging techniques and of patients' survival. Physicians in charge of GIST patients should be aware of this unusual metastatic site during the prolonged natural history of GISTs in the TKI era. We recommend attention notably in case of GISTs $>5 \mathrm{~cm}$, with a high mitotic index or with a rectal location. If bone metastasis remains a palliative disease, multiple therapeutics options (like surgery, radiotherapy, TKIs, and bisphosphonates) are available to improve symptoms and prolong survival.

\section{Acknowledgements}

Our work was supported by Institut Paoli-Calmettes and Aix-Marseille University. We thank Emilie Agavnian-Couquiau for her help in pathological scanning. We thank our patient who kindly gave his consent for this publication.

\section{Statement of Ethics}

We thank the patient who kindly gave his informed consent. The study was approved by our institutional review board.

\section{Disclosure Statement}

The authors declare no conflict of interest. 


\section{References}

-1 Kindblom LG, Remotti HE, Aldenborg F, Meis-Kindblom JM: Gastrointestinal pacemaker cell tumor (GIPACT): gastrointestinal stromal tumors show phenotypic characteristics of the interstitial cells of Cajal. Am J Pathol 1998;152:1259-1269.

- Hirota S, Isozaki K, Moriyama Y, Hashimoto K, Nishida T, Ishiguro S, Kawano K, Hanada M, Kurata A, Takeda M, Muhammad Tunio G, Matsuzawa Y, Kanakura Y, Shinomura Y, Kitamura Y: Gain-of-function mutations of c-kit in human gastrointestinal stromal tumors. Science 1998;279:577-580. Søreide K, Sandvik OM, Søreide JA, Giljaca V, Jureckova A, Bulusu VR: Global epidemiology of gastrointestinal stromal tumours (GIST): a systematic review of population-based cohort studies. Cancer Epidemiol 2016;40:39-46. Miettinen M, Lasota J: Gastrointestinal stromal tumors: review on morphology, molecular pathology, prognosis, and differential diagnosis. Arch Pathol Lab Med 2006;130:1466-1478.

5 Burkill GJ, Badran M, Al-Muderis O, Meirion Thomas J, Judson IR, Fisher C, Moskovic EC: Malignant gastrointestinal stromal tumor: distribution, imaging features, and pattern of metastatic spread. Radiology 2003;226:527-532. Jati A, Tatlı S, Morgan JA, Glickman JN, Demetri GD, Van den Abbele A, Silverman SG: Imaging features of bone metastases in patients with gastrointestinal stromal tumors. Diagn Interv Radiol 2012;18: 391-396.

7 Schuler M, Zeile M, Pink D, Tunn P, Kretzschmar A, Rau B, Reichardt P: Incidence of bone metastases in GIST: a single center analysis of 307 patients with metastatic disease. J Clin Oncol 2008;26:10565. Bertulli R, Fumagalli E, Coco P, Messina A, Morosi C, Dileo P, Casali PG; Fondazione IRCCS Istituto Nazionale dei Tumori, Milan, Italy: Unusual metastatic sites in gastrointestinal stromal tumor (GIST). ASCO Meet Abstr 2009;27:10566.

9 Chu TYC, Wong CS: Bone metastases from gastrointestinal stromal tumour: correlation with positron emission tomography-computed tomography. J Hong Kong Coll Radiol 2009;11:172-175.

-10 Gerlinger M, Rowan AJ, Horswell S, Larkin J, Endesfelder D, Gronroos E, Martinez P, Matthews N, Stewart A, Tarpey P, Varela I, Phillimore B, Begum S, McDonald NQ, Butler A, Jones D, Raine K, Latimer C, Santos CR, Nohadani M, Eklund AC, Spencer-Dene B, Clark G, Pickering L, Stamp G, Gore M, Szallasi Z, Downward J, Futreal PA, Swanton C: Intratumor heterogeneity and branched evolution revealed by multiregion sequencing. N Engl J Med 2012;366:883-892.

$\checkmark 11$ Le Cesne A, Ray-Coquard I, Bui BN, Adenis A, Rios M, Bertucci F, Duffaud F, Chevreau C, Cupissol D, Cioffi A, Emile JF, Chabaud S, Pérol D, Blay JY; French Sarcoma Group: Discontinuation of imatinib in patients with advanced gastrointestinal stromal tumours after 3 years of treatment: an open-label multicentre randomised phase 3 trial. Lancet Oncol 2010;11:942-949. Suzuki K, Yasuda T, Nagao K, Hori T, Watanabe K, Kanamori M, Kimura T: Bone metastasis of a gastrointestinal stromal tumor: a report of two cases. Oncol Lett 2015;9:1814-1818.

-13 Slimack NP, Liu JC, Koski T, McClendon J, O’Shaughnessy BA: Metastatic gastrointestinal stromal tumor to the thoracic and lumbar spine: first reported case and surgical treatment. Spine J 2012;12:e7-e12.

14 Barriere J, Thariat J, Vandenbos F, Bondiau PY, Peyrottes I, Peyrade F: Diplopia as the first symptom of an aggressive metastatic rectal stromal tumor. Onkologie 2009;32:345-347.

15 Di Scioscio V, Greco L, Pallotti MC, Pantaleo MA, Maleddu A, Nannini M, Bazzocchi A, Di Battista M, Mandrioli A, Lolli C, Saponara M, Giorgio G, Biasco G, Zompatori M: Three cases of bone metastases in patients with gastrointestinal stromal tumors. Rare Tumors 2011;3:e17.

16 Aktan M, Koc M, Yavuz BB, Kanyilmaz G: Two cases of gastrointestinal stromal tumor of the small intestine with liver and bone metastasis. Ann Transl Med 2015;3:259.

17 Nakajima T, Sugiyama T, Baba H, Hatta H, Nishida T, Miwa S, Hayashi S, Tsuneyama K, Imura J: Bone metastasis in gastrointestinal stromal tumors preferentially occurs in patients with original tumors in sites other than the stomach. Int J Clin Exp Pathol 2015;8:5955.

-18 Sahin E, Yetişyiğit T, Oznur M, Elboğa U: Gastric gastrointestinal stromal tumor with bone metastases case report and review of the literature. Klin Onkol 2014;27:56-59.

19 Feki J, Bouzguenda R, Ayedi L, Bradi M, Boudawara T, Daoud J, Frikha M: Bone metastases from gastrointestinal stromal tumor: a case report. Case Rep Oncol Med 2012;2012:509845.

-20 Selcukbiricik F, Tural D, Ozturk MA, Dervisoglu S, Sager S, Hız M, Mandel NM: Gastrointestinal stromal tumor of the rectum with scapular metastasis: a case report. J Med Case Rep 2012;6:145.

21 Abuzakhm SM, Acre-Lara CE, Zhao W, Hitchcock C, Mohamed N, Arbogast D, Shah MH: Unusual metastases of gastrointestinal stromal tumor and genotypic correlates: case report and review of the literature. J Gastrointest Oncol 2011;2:45-49. 


\section{Case Reports in Oncology}

Rochigneux et al.: Gastrointestinal Stromal Tumour with Synchronous Bone Metastases: A Case Report and Literature Review

$>22$

$>23$

Tezcan Y, Koç M: Gastrointestinal stromal tumor of the rectum with bone and liver metastasis: a case study. Med Oncol 2011;28 (suppl 1):S204-S206.

Jain A, Dubashi B, Mangaladevi, Chandra SS, Halanaik D: Mesenteric gastrointestinal stromal tumor with bone metastases. Indian J Cancer 2011;48:383-384.

Baeg MK, Bae SH, Lee KH, Kim J, Park IS, Jin JY: Diplopia as a presenting symptom in a gastric gastrointestinal stromal tumor. Jpn J Clin Oncol 2011;41:265-268.

Li LF, Tse YH, Ho SL, Yan KW, Lui WM: Duodenal GIST metastasized to skull and orbit managed by surgery: a case report. Asian J Surg 2011;34:181-184.

Wong CS, Chu YC: Intra-cranial metastasis of gastrointestinal stromal tumor. Chin Med J (Engl) 2011;124:3595-3597.

Lolli C, Pantaleo MA, Nannini M, Saponara M, Pallotti MC, Scioscio VD, Barbieri E, Mandrioli A, Biasco G: Successful radiotherapy for local control of progressively increasing metastasis of gastrointestinal stromal tumor. Rare Tumors 2011;3:e49.

Zheng CK, Kan WS, Li P: A case report of a metastatic gastrointestinal stromal tumor occurring in femur. Case Rep Gastrointest Med 2011;2011:926179.

Romero-Rojas AE, Mesa-Botero OA, Melo-Uribe MA, Chinchilla-Olaya SI, Barajas-Solano PA: Gastric gastrointestinal stromal tumor with unusual skull metastasis. Rev Col Gastroenterol 2011;26:303-307. Ozan E, Oztekin O, Alacacioğlu A, Aykaş A, Postaci H, Adibelli Z: Esophageal gastrointestinal stromal tumor with pulmonary and bone metastases. Diagn Interv Radiol 2010;16:217-220.

Gil-Arnaiz I, Martínez-Trufero J, Pazo-Cid RA, Felipo F, Lecumberri MJ, Calderero V: Skull metastasis from rectal gastrointestinal stromal tumours. Clin Transl Oncol 2009;11:625-627.

Gong L, Li YH, Zhao HD, Zhao JY, Zhang W: The clinicopathologic observation, c-KIT gene mutation and clonal status of gastrointestinal stromal tumor in the sacrum. BMC Gastroenterol 2009;9:43.

Lutz JC, El-Bouihi M, Vidal N, Fricain JC, Robert M, Deminière C, Zwetyenga N: Mandibular metastases from an ileum stromal tumor. Rev Stomatol Chir Maxillofac 2008;109:399-402.
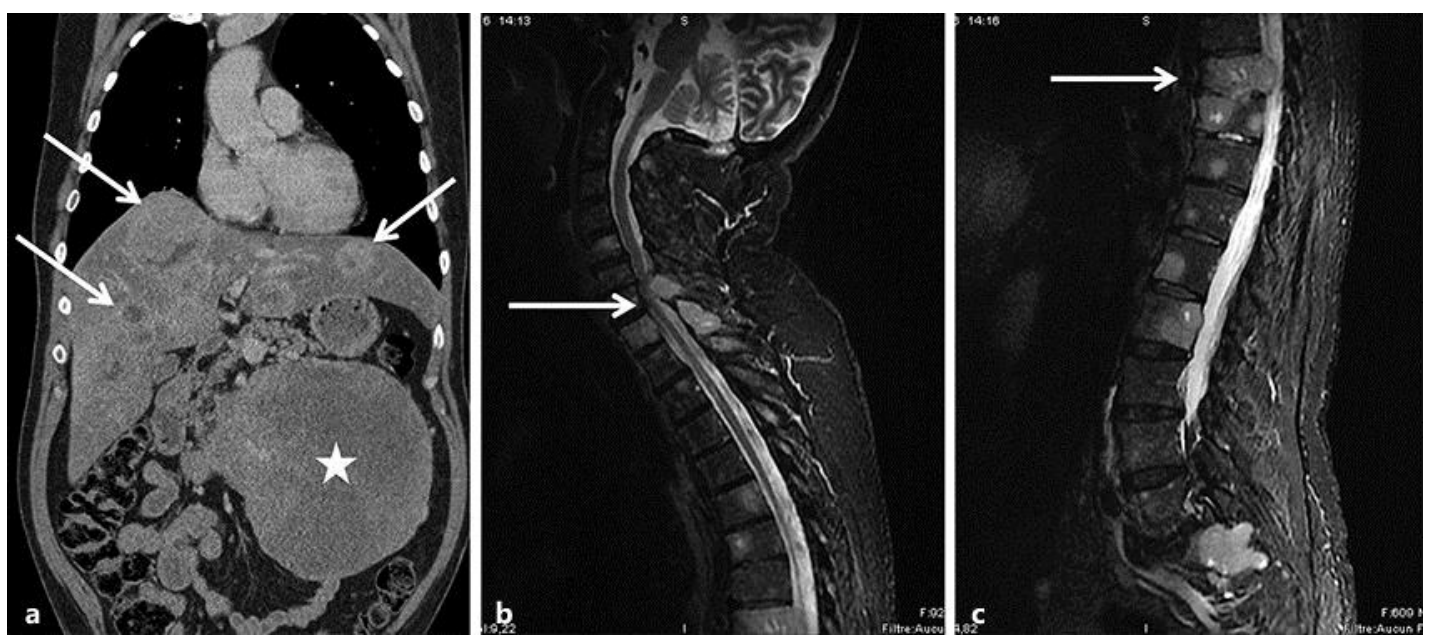

Fig. 1. Gastrointestinal stromal tumour (GIST) with liver and bone metastases: radiological aspects. a Thoraco-abdomino-pelvic CT scan in the coronal plane showing the huge gastric GIST (star) and multiple bilateral liver metastases (arrows). b, c Magnetic resonance imaging of the spine in the sagittal plane, T2 sequence, showing the multiple bone vertebral lesions (notably in C7, T1, and T9), the sacrum, and a T1 and T9 epiduritis (arrows). 


\section{Case Reports in Oncology}

Case Rep Oncol 2017;10:66-76
\begin{tabular}{l|l}
\hline DOI: $10.1159 / 000455188$ & $\begin{array}{l}\text { C } 2017 \text { The Author(s). Published by S. Karger AG, Basel } \\
\text { www.karger.com/cro }\end{array}$
\end{tabular}

Rochigneux et al.: Gastrointestinal Stromal Tumour with Synchronous Bone Metastases: A Case Report and Literature Review
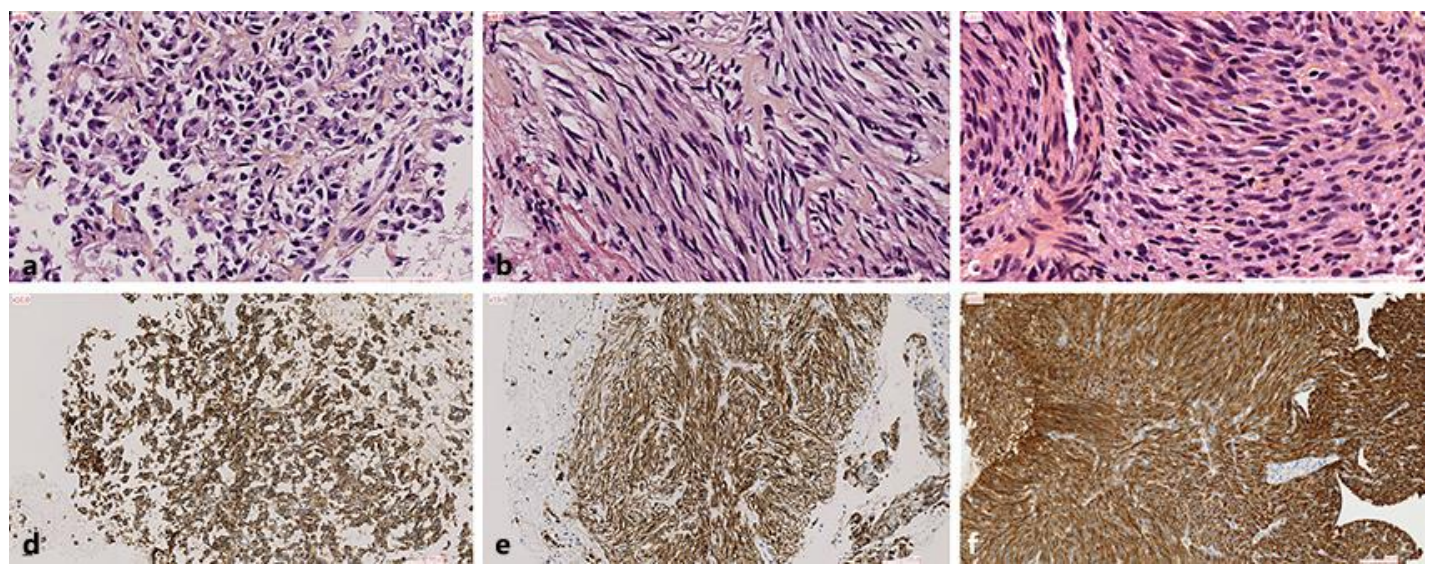

Fig. 2. Gastrointestinal stromal tumour (GIST) with liver and bone metastases: pathological aspects. a-c HES microphotographies showing 2 distinctive morphological patterns of GIST: epithelioid cells on gastric biopsy (a) as well as spindle cells on hepatic (b) and bone (c) metastases. $\mathbf{d - f}$ Immunohistochemistry staining showing expression by tumour cells (epithelioid and spindle cells) of CD117/KIT (d-f) and DOG1 (e).
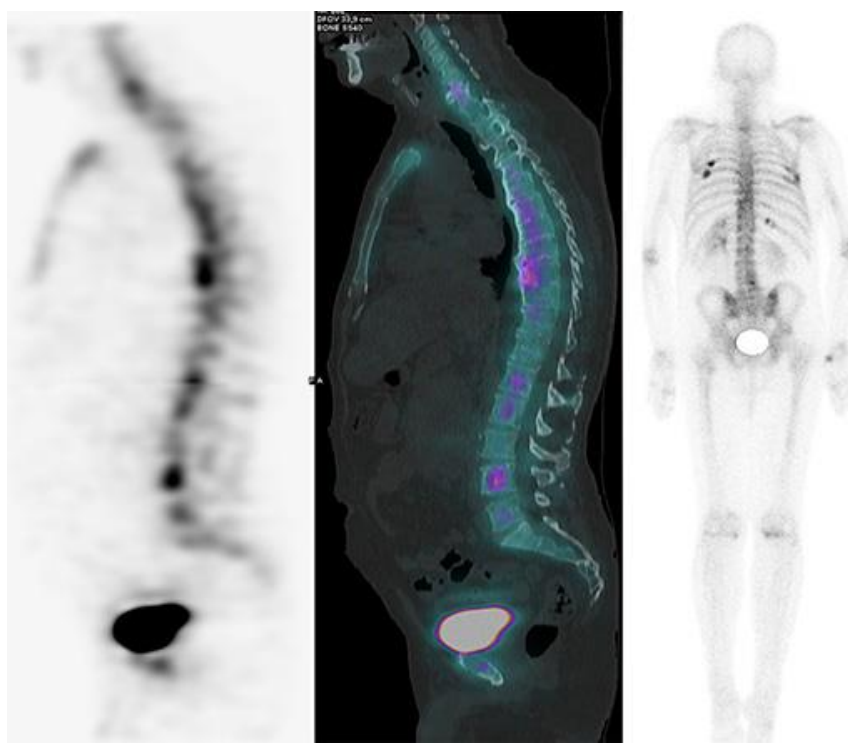

Fig. 3. ${ }^{99 m}$ Tc-labelled bone scintigraphy showing multiple lesions (bone uptakes) of the cervico-dorsolumbar spine, the pelvis, the ribs, and the clavicles. 


\section{Case Reports in Oncology}

\begin{tabular}{l|l} 
DOI: $10.1159 / 000455188$ & (C) 2017 The Author(s). Published by S. Karger AG, Basel
\end{tabular} www.karger.com/cro

Rochigneux et al.: Gastrointestinal Stromal Tumour with Synchronous Bone Metastases: A Case Report and Literature Review

Table 1. Pathological and molecular characteristics of the primary tumour and the metastases

\begin{tabular}{llll}
\hline Characteristics & Gastric tumour & Liver metastasis & Bone metastasis \\
\hline Morphology & epithelioid & spindle cells & spindle cells \\
\hline Mitotic index & $<5 / 50 \mathrm{HPFs}$ & $<5 / 50 \mathrm{HPFs}$ & $<5 / 50 \mathrm{HPFs}$ \\
\hline IHC staining & CD34- & CD34+ & CD34+ \\
& CD117/KIT+ & CD117/KIT+ & CD117/KIT+ \\
& DOG1+ & DOG1+ & DOG1+ \\
\hline KIT mutational status & exon 11 & wild type & exon 11 \\
& c.1676_1714del & & c.1676_1714del \\
\hline$P D G F R A$ mutational status & wild type & wild type & wild type \\
\hline
\end{tabular}

HPFs, high-power fields; IHC, immunohistochemistry. 
Rochigneux et al.: Gastrointestinal Stromal Tumour with Synchronous Bone Metastases:

A Case Report and Literature Review

Table 2. Literature review of 37 patients with primary GIST and bone metastases: characteristics of primary GIST

\begin{tabular}{|c|c|c|c|c|c|c|}
\hline $\begin{array}{l}\text { Ref. } \\
\text { No. }\end{array}$ & $\begin{array}{l}\text { Sex, } \\
\text { age }\end{array}$ & Site & Pathological type & Mitosis (/HPFs) & KIT IHC & Mutational status \\
\hline $\begin{array}{l}\text { Our } \\
\text { case }\end{array}$ & M, 66 & stomach & epithelioid & $<5 / 50$ & positive & $\begin{array}{l}\text { KIT exon } 11 \\
\text { (c.1676_1714del) }\end{array}$ \\
\hline 16 & M, 56 & jejunum, ileum & epithelioid + spindle & $12 / 50$ & positive & NA \\
\hline 16 & M, 70 & ileum & epithelioid + spindle & $20 / 50$ & positive & NA \\
\hline 12 & M, 78 & stomach & NA & NA & NA & NA \\
\hline 12 & $\mathrm{M}, 41$ & rectum & NA & NA & positive & NA \\
\hline 17 & M, 76 & rectum & spindle & $20 / 50$ & NA & NA \\
\hline 17 & M, 43 & jejunum & spindle & $19 / 50$ & NA & NA \\
\hline 17 & $M, 50$ & rectum & spindle & $15 / 50$ & NA & NA \\
\hline 17 & $\mathrm{M}, 50$ & jejunum & spindle & $15 / 50$ & NA & NA \\
\hline 18 & M, 62 & stomach & epithelioid + spindle & $7 / 50$ & positive & NA \\
\hline 19 & M, 58 & jejunum & spindle & low & positive & NA \\
\hline 6 & M, 49 & stomach & NA & $27 / 50$ & positive & NA \\
\hline 6 & $\mathrm{M}, 71$ & rectum & NA & $41 / 50$ & positive & NA \\
\hline 6 & $\mathrm{~F}, 52$ & stomach & NA & $40 / 50$ & positive & NA \\
\hline 6 & $\mathrm{M}, 48$ & stomach & NA & $12 / 50$ & positive & NA \\
\hline 6 & M, 51 & stomach & NA & $22 / 50$ & positive & NA \\
\hline 6 & $\mathrm{M}, 60$ & jejunum & NA & $6 / 50$ & positive & NA \\
\hline 20 & $\mathrm{M}, 54$ & rectum & spindle & NA & positive & NA \\
\hline 13 & M, 37 & duodenum & NA & NA & positive & NA \\
\hline 21 & $\mathrm{~F}, 57$ & jejunum & spindle & $<5 / 50$ & positive & NA \\
\hline 22 & M, 83 & rectum & NA & NA & positive & NA \\
\hline 23 & M, 55 & mesentery & epithelioid + spindle & $10-15 / 50$ & positive & NA \\
\hline 24 & $\mathrm{M}, 70$ & stomach & spindle & $21 / 50$ & positive & NA \\
\hline 25 & M, 26 & duodenum & epithelioid & $<5 / 50$ & positive & NA \\
\hline 15 & $\mathrm{M}, 62$ & ileum & NA & NA & NA & NA \\
\hline 15 & $\mathrm{~F}, 82$ & stomach & NA & $16 / 50$ & positive & $\begin{array}{l}\text { KIT exon } 11 \\
\text { (c.1696_1718del) }\end{array}$ \\
\hline 15 & $\mathrm{~F}, 54$ & duodenum & NA & $>5 / 50$ & positive & $\begin{array}{l}\text { KIT exon } 11 \\
\text { T>A } 69429\end{array}$ \\
\hline 26 & M, 26 & duodenum & NA & NA & positive & NA \\
\hline 27 & $\mathrm{~F}, 48$ & ileum & NA & $>10 / 50$ & positive & $\begin{array}{l}\text { KIT exon } 11 \\
\text { (c.1657_1674del) }\end{array}$ \\
\hline 28 & $\mathrm{M}, 62$ & stomach & spindle & NA & positive & $\begin{array}{l}\text { KIT exon } 11 \\
\text { (codons 557/558) }\end{array}$ \\
\hline 29 & M, 38 & stomach & spindle & $>5 / 50$ & positive & NA \\
\hline 30 & M, 53 & oesophagus & NA & $5-10 / 50$ & positive & NA \\
\hline 14 & $\mathrm{M}, 57$ & rectum & spindle & NA & positive & NA \\
\hline 31 & M, 65 & rectum & spindle & NA & positive & NA \\
\hline 9 & M, 73 & stomach & epithelioid + spindle & NA & positive & NA \\
\hline 32 & $\mathrm{~F}, 50$ & NA & NA & NA & NA & NA \\
\hline 33 & M, 68 & ileum & epithelioid + spindle & $<5 / 50$ & positive & NA \\
\hline
\end{tabular}

GIST, gastrointestinal stromal tumour; HPFs, high-power fields; IHC, immunohistochemistry; NA, not available. 
Table 3. Literature review of 37 patients with primary GIST and bone metastases: characteristics of bone metastases

\begin{tabular}{|c|c|c|c|c|c|c|c|c|c|}
\hline $\begin{array}{l}\text { Ref. } \\
\text { No. }\end{array}$ & $\begin{array}{l}\text { Sex, } \\
\text { age }\end{array}$ & Chronologya & Site & $\begin{array}{l}\text { Patho- } \\
\text { logical } \\
\text { type }\end{array}$ & $\begin{array}{l}\text { KIT } \\
\text { IHC }\end{array}$ & $\begin{array}{l}\text { Mutational } \\
\text { status }\end{array}$ & $\begin{array}{l}\text { Other } \\
\text { metastasis }^{\mathrm{b}}\end{array}$ & Treatment & Outcome ${ }^{c}$ \\
\hline $\begin{array}{l}\text { Our } \\
\text { case }\end{array}$ & M, 66 & synchronous & spine, pelvis & spindle & pos & $\begin{array}{l}\text { KIT exon } 11 \\
\text { (c.1676_1714del) }\end{array}$ & $\mathrm{L}$ & I & alive: $9 \mathrm{~m}$ \\
\hline 16 & M, 56 & $4 \mathrm{~m}$ & spine (L1-L3), femur & $\mathrm{NA}(\mathrm{NB})$ & NA & NA & $\mathrm{L}$ & $\mathrm{I}+\mathrm{RT}+\mathrm{Bi}$ & death: $2 \mathrm{~m}$ \\
\hline$\overline{16}$ & M, 70 & $5 \mathrm{~m}$ & spine (L2) & NA (NB) & NA & NA & $\mathrm{L}$ & $\mathrm{I}+\mathrm{RT}+\mathrm{Bi}$ & death: $1.5 \mathrm{~m}$ \\
\hline$\overline{12}$ & M, 78 & $60 \mathrm{~m}$ & femur & spindle & pos & NA & no & $\begin{array}{l}\text { Surg (prosthesis) } \\
+\mathrm{I}\end{array}$ & alive: $48 \mathrm{~m}$ \\
\hline$\overline{12}$ & M, 41 & $84 \mathrm{~m}$ & rib (K4) & spindle & pos & NA & no & Surg+I & alive: $120 \mathrm{~m}$ \\
\hline$\overline{17}$ & M, 76 & $49 \mathrm{~m}$ & spine (thoracic) & NA & NA & NA & no & I & death: $103 \mathrm{~m}$ \\
\hline$\overline{17}$ & $\mathrm{M}, 43$ & $81 \mathrm{~m}$ & spine (cervical/lumbar) & NA (NB) & NA & NA & $\mathrm{L}$ & Sun & alive: NA \\
\hline$\overline{17}$ & M, 50 & $108 \mathrm{~m}$ & spine (cervical), rib & NA (NB) & NA & NA & $\mathrm{L}$ & I & alive: 187 m \\
\hline$\overline{17}$ & $\mathrm{M}, 50$ & $104 \mathrm{~m}$ & spine (thoracic/lumbar) & NA (NB) & NA & NA & L, P & no & death: $1 \mathrm{~m}$ \\
\hline$\overline{18}$ & M, 62 & $6 \mathrm{~m}$ & skull, rib, sacroiliac & NA (NB) & NA & NA & no & I & alive: NA \\
\hline$\overline{19}$ & M, 58 & $28 \mathrm{~m}$ & sternoclavicular, T1-T10 & spindle & pos & NA & $\mathrm{L}$ & $\mathrm{I}+\mathrm{RT}$ & alive: $19 \mathrm{~m}$ \\
\hline 6 & M, 49 & NA & & NA (NB) & NA & NA & $\begin{array}{l}\text { L, S, P, } \\
\text { LN, ST }\end{array}$ & NA & NA \\
\hline 6 & M, 71 & NA & spine $(n=4)$ & NA (NB) & NA & NA & $\mathrm{P}, \mathrm{L}$ & NA & NA \\
\hline 6 & $\mathrm{~F}, 52$ & NA & pelvis $(n=4)$ & NA (NB) & NA & NA & $\mathrm{P}, \mathrm{L}$ & NA & NA \\
\hline 6 & $\mathrm{M}, 48$ & NA & ribs $(n=4)$ & NA (NB) & NA & NA & $\mathrm{P}, \mathrm{L}$ & NA & NA \\
\hline 6 & M, 51 & NA & femur $(n=3)$ & NA (NB) & NA & NA & L, P, ST & NA & NA \\
\hline 6 & $\mathrm{M}, 60$ & NA & & $\mathrm{NA}(\mathrm{NB})$ & NA & NA & $\mathrm{L}$ & NA & NA \\
\hline$\overline{20}$ & M, 54 & $120 \mathrm{~m}$ & scapula & spindle & pos & NA & $\mathrm{L}$ & Surg+Sun & alive: $24 \mathrm{~m}$ \\
\hline$\overline{13}$ & M, 37 & $36 \mathrm{~m}$ & spine (thoracic/lumbar) & NA & pos & NA & $\mathrm{L}$ & Surg+I+RT & alive: $24 \mathrm{~m}$ \\
\hline$\overline{21}$ & $\mathrm{~F}, 57$ & $49 \mathrm{~m}$ & humerus & spindle & pos & NA & $\mathrm{L}, \mathrm{Pl}$ & Sun+RT & death: $7 \mathrm{~m}$ \\
\hline$\overline{22}$ & $\mathrm{M}, 83$ & $12 \mathrm{~m}$ & hip/femur & NA & NA & NA & $\mathrm{L}$ & $\mathrm{I}+\mathrm{RT}+\mathrm{Bi}$ & alive: NA \\
\hline$\overline{23}$ & M, 55 & $36 \mathrm{~m}$ & skull, rib, spine (T9-T10) & NA (NB) & NA & NA & $\mathrm{L}$ & I & alive: $6 \mathrm{~m}$ \\
\hline$\overline{24}$ & $\mathrm{M}, 70$ & synchronous & clivus, ribs & NA & pos & NA & $\mathrm{L}, \mathrm{Lg}$ & I & alive: $2 \mathrm{~m}$ \\
\hline$\overline{25}$ & M, 26 & $72 \mathrm{~m}$ & temporal bone/orbit & NA & pos & NA & $\mathrm{L}$ & Surg+RT+Nilo & NA \\
\hline$\overline{15}$ & M, 62 & synchronous & spine, ribs, pelvis & $\mathrm{NA}(\mathrm{NB})$ & NA & NA & $\mathrm{L}$ & $\mathrm{I} / \mathrm{Sun}+\mathrm{RT}+\mathrm{Bi}$ & death: $34 \mathrm{~m}$ \\
\hline$\overline{15}$ & $\mathrm{~F}, 82$ & synchronous & spine, pelvis & NA & NA & NA & $\mathrm{L}$ & $\mathrm{I} / \mathrm{Sun}+\mathrm{Bi}$ & alive: $44 \mathrm{~m}$ \\
\hline$\overline{15}$ & $\mathrm{~F}, 54$ & $84 \mathrm{~m}$ & spine, pelvis, ribs & NA (NB) & NA & NA & $\mathrm{L}$ & Sun & death: $16 \mathrm{~m}$ \\
\hline$\overline{26}$ & M, 26 & $72 \mathrm{~m}$ & skull (frontotemporal) & NA (NB) & NA & NA & $\mathrm{L}$ & Surg+I/Sun+RT & alive: $4 \mathrm{~m}$ \\
\hline$\overline{27}$ & $\mathrm{~F}, 48$ & $46 \mathrm{~m}$ & clavicle & NA (NB) & NA & NA & $\mathrm{P}$ & Soraf+RT & alive: $12 \mathrm{~m}$ \\
\hline$\overline{28}$ & M, 62 & $28 \mathrm{~m}$ & femur & spindle & pos & $\begin{array}{l}\text { KIT exon } 11 \\
\text { (codons 557/558) }\end{array}$ & no & Surg (graft)+I & alive: $12 \mathrm{~m}$ \\
\hline 29 & M, 38 & $38 \mathrm{~m}$ & skull (frontoparietal) & spindle & pos & NA & $\mathrm{L}, \mathrm{LN}$ & NA & NA \\
\hline 30 & $\mathrm{M}, 53$ & synchronous & humerus & NA (NB) & NA & NA & $\mathrm{Lg}$ & I & alive: NA \\
\hline$\overline{14}$ & M, 57 & synchronous & clivus, temporal bone & spindle & pos & NA & $\mathrm{L}, \mathrm{Lg}$ & I/Sun/Nilo+RT & death: $17 \mathrm{~m}$ \\
\hline$\overline{31}$ & $\mathrm{M}, 65$ & synchronous & frontoparietal skull & NA (NB) & NA & NA & $\mathrm{L}$ & I & NA \\
\hline 9 & $\mathrm{M}, 73$ & $6 \mathrm{~m}$ & $\begin{array}{l}\text { spine (T6), pelvis, } \\
\text { clavicle }\end{array}$ & NA (NB) & NA & NA & L, P, S, PC & I & NA \\
\hline$\overline{32}$ & $\mathrm{~F}, 50$ & prevalent & sacrum & spindle & pos & $\begin{array}{l}\text { KIT exon } 11 \\
\text { (del } 15 \mathrm{bp}, \\
\text { position } 100 \text { ) }\end{array}$ & no & Surg & NA \\
\hline 33 & M, 68 & synchronous & mandible & NA & pos & NA & no & I & death: $11 \mathrm{~m}$ \\
\hline
\end{tabular}

Bi, bisphosphonates; I, imatinib; L, liver; Lg, lung; LN, lymph node; m, month(s); NA, not available; NB, no biopsy; Nilo, nilotinib; P, peritoneum; PC, pancreas; Pl, pleural; pos, positive; RT, radiotherapy; S, spleen; Soraf, sorafenib; ST, soft tissue; Sun, sunitinib; Surg, surgery. a Time in months between the diagnosis of primary gastrointestinal stromal tumour and bone metastasis. ${ }^{b}$ Other metastasis before or at the diagnosis of bone metastasis. ${ }^{c}$ Outcome in months from the diagnosis of bone metastasis. 